\section{O-233堅細胞癌に対する腹䏸鏡下腎部分切除術の 検討}

\author{
大分医科大学" \\ 世崎 義久" 佐藤 文憲" 笠木 泰弘" 三股 浩光" \\ 野村 芳雄!
}

【目的】腎細胞癌に対し腹腔鏡下腎部分切除術を施行し、その有 用性と問題点を唡討した。【対象】男性患者4症例で、平均年齢 64.5才(38〜 75才)。全例偶発癌であり、畽瘍径は2 3 $\mathrm{cm}$ (平均 $2.5 \mathrm{~cm}$ )、右側2例, 左側 2 例である。【j法】1例は胃後方の腫㢞 を合併しており外科が腹胿鏡下腫瘤摘除術を行った後、引き続き 経腹䏶的到達法にて腎腫瘍周囲を剥離し、マイク口波組織凝固装 置を用い、腫瘍成讲を凝固, 解離の後、鋭的に切除した。他の 3例は経後腹膜的側方到達法にて同様に行った。【結果】4症例の 平均手術時間は201分（150２65分），汮出血量は245g（70～ $510 \mathrm{~g}$ ) で、全例よも翌日より経口摃取および歩行可能であった。 合併症として3例に術後尿漏机を生じた。1例は自然閉鎖し、1例 は瓜管ステント留置にて閉鎖したが、1例のみ尿漏上感染が遷延 し、術後4ヶ月目に篎摘除術を施行した，術後創治癒の遷延も市 り、5ケ月日にようやく退院となった。【考察】腹腔鏡下㛑部分 切除術を行うには、マイクロ波組織凝国装置の使用が必須である。 その使用に際し、腫瘍残存を恐れるあまり広範に凝固しすぎる傾 问にある。また、周囲婜組織の変性は照いのほか広範である。こ れらを留意し症例を適切に選択すれば、腹腔鏡下部分切除術は非 常に有用な術式と思われる。

\section{腎細胞癌 腹腔鏡下腎部分切除術}

\section{O-235両倒副腎腫場に対する腹䏷鏡下手術 5 例の 検討}

\section{北海道大学 大学院医学研究科 腎泌尿器外科}

飴田要”柿崎秀宏" 原林透”篠原信雄" 安部崇重” 野々村克也"小柳知彦”

【日的】両側副腎腫瘍に対する腹胿鏡专術の成績を供覧し、その 有用性・問題点を考察する。【対象】MENtypeIIAに伴う褐色細 胞腫2例、ACTH非依存性両側副腎皮質大結節過形成 (AIMAH)2 例、両側褐色細胞腫1例（男性4例、女性1例、手術施行時年.齢 33 -61 才)。【結果】最初の 2 例は二期的、後半の3例は一期的手術 を行った。例で左経腹僋方・右経腹前方、1例で一期的経後腹膜 後方アプローチを用いた。褐色細胞腫の2例では一部、正常副腎 を温存した。腫瘍最大待は25-150mm (中央値 $60 \mathrm{~mm}$ )、摘出腫 場重量は13-108 g（中央值40g) であ二た。手術時間は二期的手 術で計565分、640分、一期的手術では389分-560分であった。一 側あたりの出欰量は50-700ml (中央値 $140 \mathrm{ml}$ )、重篤な術中合併 症はなかった。全例術翌日より歩行可能であり、経口を再開した。 周術期の合併症として、1例で摘出創感染、1例でTIA（脳梗塞既 往、抗凝固剂内服例）を誹めたが、重篤なものを認めず、輸血を 要した症例もなかった。【考察】腹腔鏡下手術は周術期の全身管 理が容易であり、巨大副腎腫瘍や両側裀色細胞腫に対しても安全 に施行可能である。手術手技の向上、周辺機器の発展に伴い、一 期的于術はより低㻏襲之なりつつある。

\section{$0-234$}

腎摘出クリニカルパス導入前後の医療内容 の変化について

\author{
済生会熊本病院 腎泌尿器センター"

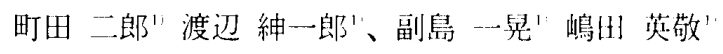 \\ 田居さえ子”“副鳥秀久
}

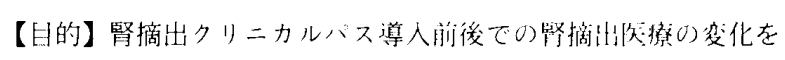
検証しクリニカルバスの意義を評価する。【対象】将成8俳1月か ら平成12年10月までに腎摘出術を受けた60例。【引注】クリ二カ ルパスは平成10年から寒施した。平战11俳までは開腹丁術、壮成

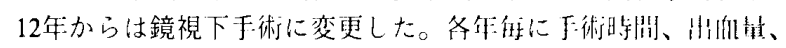

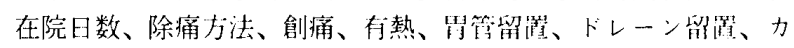
テーテル留置、抗生物質投! 補液の期間、食事開始、少行開始

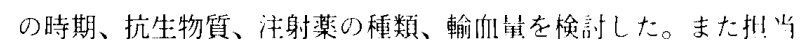
[医間の差について検討した。【結果】クリニカルバス導入により 在院日数、筒管、ドレーン、バルーンカテーテル留置期间、食临、 步行開始時期、補液期間は作々知維倾们となり鏡視下于術变建に より明かに短縮された。またアルブミン、ビタミン剂などの使州 頻度も減少した。抗生物毁门種類は統一さ机、投'j期閒屯知縮さ れたが術後感染症の発症に变化は見ら扎なかった。釗惊、们熟期

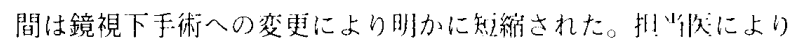

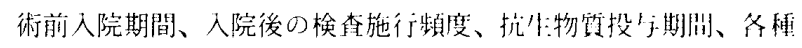

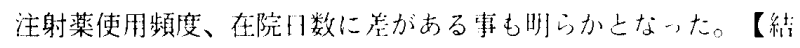
論】クリニカルパスは医撩の標準化を行なうための们用な丁段で

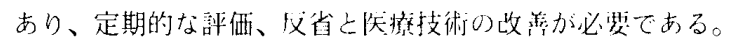

腎摘出 クリニカルパス

\section{O-236腎腫瘍に対する腹複鏡下手術}

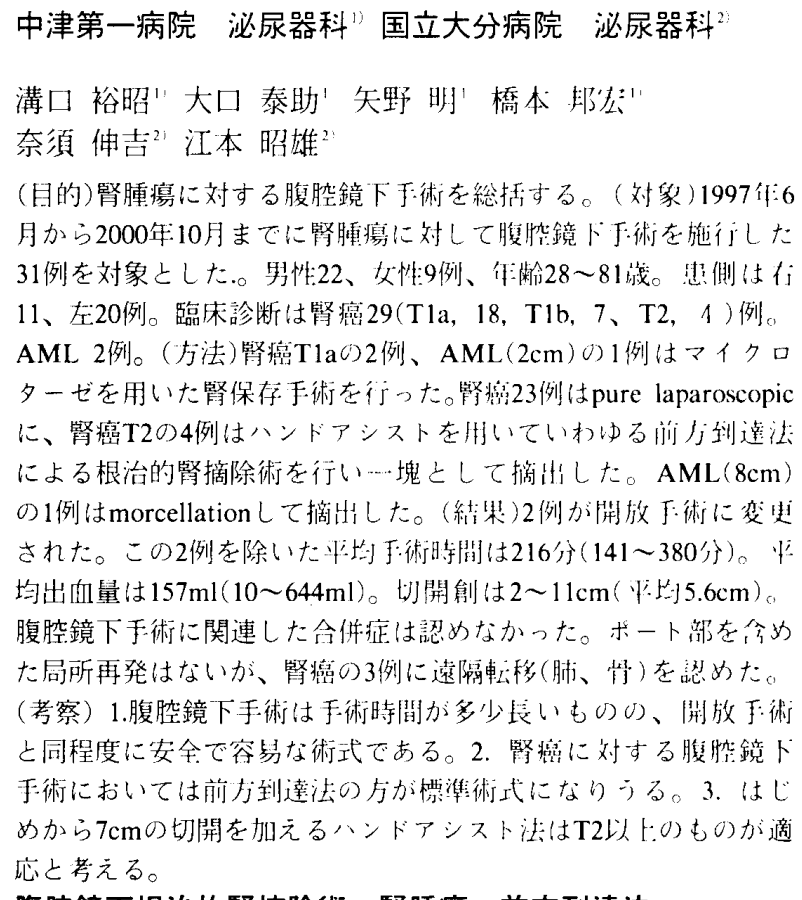
腹腔鏡下根治的腎摘除術 腎腫瘍 前方到達法 